\title{
Cross-cultural adaptation of the Work Disability Diagnosis Interview (WoDDI) for the Brazilian context
}

\author{
Vivian Aline Mininel${ }^{2}$ \\ Vanda Elisa Andres Felli ${ }^{3}$ \\ Patrick Loisel ${ }^{4}$ \\ Maria Helena Palucci Marziale ${ }^{5}$
}

\begin{abstract}
The Work Disability Diagnosis Interview (WoDDI) is a structured interview guide developed by the University of Sherbrooke, Canada to help clinicians detect the most important workrelated disability predictors and to identify one or more causes of prolonged absenteeism. This methodological study aims for the cross-cultural adaptation of the WoDDI for the Brazilian context. The method followed international guidelines for studies of this kind, including the following steps: initial translation, synthesis of translations, back translation, evaluation by an expert committee and testing of the penultimate version. These steps allowed obtaining conceptual, semantic, idiomatic, experiential and operational equivalences, in addition to content validity. The results showed that the translated WoDDI is adapted to the Brazilian context and can be used after training.
\end{abstract}

Descriptors: Translating; Work Capacity Evaluation; Occupational Health; Diagnosis of Health Situation in Specific Groups.

\footnotetext{
${ }^{1}$ Supported by Work Disability Prevention Canadian Institutes of Health Research (CIHR) Strategic Training Program grant(s) FRN: 53909.

${ }^{2}$ RN, Ph.D. in Sciences, Researcher, Escola de Enfermagem, Universidade de São Paulo, SP, Brazil. E-mail: vivian.aline@usp.br.

${ }^{3}$ RN, Ph.D. in Nursing, Associate Professor, Escola de Enfermagem, Universidade de São Paulo, SP, Brazil. E-mail: vandaeli@usp.br.

${ }^{4}$ Physician, Professor, Dalla Lana School of Public Health, University of Toronto, Canada. E-mail: patrick.loisel@utoronto.ca.

${ }^{5}$ RN, Ph.D. in Nursing, Full Professor, Escola de Enfermagem de Ribeirão Preto, Universidade de São Paulo, WHO Collaborating Centre for Nursing Research Development, SP, Brazil. E-mail: marziale@eerp.usp.br.
}

Corresponding Author: Vanda Elisa Andres Felli Universidade de São Paulo. Escola de Enfermagem Departamento de Orientação Profissional

Av. Dr. Enéas de Carvalho Aguiar, 419 Bairro: Cerqueira Cesar

CEP: 05.403-000 São Paulo, SP, Brasil

E-mail:vandaeli@usp.br 


\section{Adaptação transcultural do Work Disability Diagnosis Interview (WoDDI) para o contexto brasileiro}

O Work Disability Diagnosis Interview (WoDDI) é um guia de entrevista estruturada, desenvolvido pela Universidade de Sherbrooke (Canadá), para ajudar os profissionais de saúde a detectarem os fatores preditivos de maior importância para incapacidades relacionadas ao trabalho, e a identificarem uma ou mais causas de absenteísmo prolongado do trabalho. Este estudo metodológico objetivou a adaptação transcultural do WoDDI para o contexto brasileiro. O método obedeceu às recomendações internacionais para esse tipo de estudo, contemplando as seguintes fases: tradução inicial, síntese das traduções, retrotradução, avaliação por comitê de especialistas e teste da versão pré-final. Tais etapas permitiram o alcance das equivalências conceitual, semântica, idiomática, experiencial e operacional, além da validação de conteúdo. Os resultados demonstraram que o WoDDI traduzido está adaptado para a realidade brasileira e pode ser utilizado após treinamento prévio.

Descritores: Tradução; Avaliação da Capacidade de Trabalho; Saúde do Trabalhador; Diagnóstico da Situação de Saúde em Grupos Específicos.

\section{Adaptación transcultural del Work Disability Diagnosis Interview (WoDDI) para el contexto brasileño}

El Work Disability Diagnosis Interview (WoDDI) es una guía de entrevista estructurada desarrollada por la Universidad de Sherbrooke (Canadá), para ayudar a los profesionales de la salud a detectar los predictores de mayor importancia para personas con trastornos relacionados con el trabajo y para identificar una o más causas de ausentismo prolongado del trabajo. Este estudio metodológico se dirige a la adaptación transcultural (WoDDI) para el contexto brasileño. El método siguió las recomendaciones internacionales para este tipo de estudio, el que comprende las siguientes etapas: traducción inicial, síntesis de las traducciones, retraducción, revisión del comité de expertos y prueba de la versión pre-final. Estas medidas permitieron obtener la equivalencia conceptual, semántica, idiomática y la experiencia operacional, además de la validación del contenido. Los resultados mostraron que el WoDDI traducido se adapta a la realidad brasileña e puede ser utilizado, después de la capacitación previa.

Descriptores: Traducción; Evaluación de Capacidad de Trabajo; Salud Laboral; Diagnóstico de la Situación en Salud en Grupos Específicos.

\section{Introduction}

The relationship of Brazilian workers with their work context has translated into exhaustion, recurrent leave, and early retirement, all resulting from a fragile, disconnected national policy with operational problems. Research with workers from the hospital industry verifies this statement and indicates the urgency of intervention actions in this scope ${ }^{(1-6)}$.

This profile of morbidity among workers results from an environment conducive to the development of disabilities - a context that generates mixed feelings of suffering and pleasure and exposes workers to multiple workloads, leading to recurrent leave and long periods or isolated events of absenteeism, which mask reality.
According to Social Security data, musculoskeletal disorders are the main causes of reported occupational disease in Brazil(7). In general, people with such disorders present substantial degrees of disability, poor rates of return to work, and high socioeconomic costs associated with time off work $^{(8)}$.

Despite the irrefutable relationship between musculoskeletal disorders and the development of disabilities, other equally relevant intervenient factors are not always considered, such as the current social security policy, organizational barriers and sociocultural context. Psychosocial variables also clearly influence the rehabilitation process of injured workers and the results of returning to work. 
The professionals working in the initial assessment process, rehabilitation and professional reintegration of workers, do not assign the proper value to this context, whether they are linked to the National Institute of Social Security (INSS)*, to employers or public health services, they perform their activities isolated from any cooperation or communication. These professional do not have the tools enabling them to delineate the real situation of impairment and mainly rely on diagnostic exams as evidence of injury.

No studies addressing the support provided to professionals in the analysis of cases, in the definition of periods of leave, planning of connected actions to rehabilitate workers and provide them with the conditions to return to work, were found in the literature review. At least, nothing was found that matched the complexity of the situation, not restricted only to individual health conditions, but also addressing the work environment, relationships with other workers and superiors, participation of employers during the process, history of leave, integration of actions directed to the workers, and addressing the workers' fears and expectations as well as those of their family members.

There are some research instruments already validated in Brazil that support part of this process, especially in relation to the validation of the workers' health conditions ${ }^{(9-12)}$. These research tools are extremely useful in evaluating certain factors related to occupational disability, but they fragment the analysis by workers' body segments or by their ability to perform tasks, deepening the focus of analysis.

For this reason, this study emerged from the unprecedented intent to adapt an interview guide that establishes the situational diagnosis of workrelated disability to the Brazilian context, under the various perspectives that involve this context. For that, a cross-cultural adaptation of the Work Disability Diagnosis Interview was conducted ${ }^{(13)}$. It is a structured interview guide originally written in French, developed by the Sherbrooke University in Canada to help health professionals to detect the major predictors of workrelated disabilities and identify one or more causes of prolonged absenteeism ${ }^{(14)}$.

Unlike other research tools investigating healthrelated situations, the WoDDI is grounded in its own innovative methodology to approach disabilities, which constitutes the Sherbrooke Model(15). This interview guide fills in an important gap in knowledge and also provides tools for health professionals to identify occupational disabilities early.

The WoDDI contains open questions concerning physical, psychosocial, occupational and administrative factors, distributed into ten areas totaling 28 pages as described in Figure 1.

\begin{tabular}{|c|c|}
\hline Sections & Analyzed items \\
\hline 1. History of present illness & $\begin{array}{l}\text { 1.1 Age; } 1.2 \text { Position or function; } 1.3 \text { Reason for consultation; } 1.4 \text { Date of the accident/onset of } \\
\text { symptoms; } 1.5 \text { Current illness (including description of the accident); } 1.6 \text { Pathway; } 1.7 \text { Previous } \\
\text { or current treatments; } 1.8 \text { Previous exams; } 1.9 \text { Medical consultation; } 1.10 \text { Connotation of the } \\
\text { provided diagnosis. }\end{array}$ \\
\hline 2. Pain syndrome & $\begin{array}{l}2.1 \text { Characteristics of current pain; } 2.2 \text { Join stiffness; } 2.3 \text { Intermittent claudication; } 2.4 \text { Cauda } \\
\text { equine syndrome; } 2.5 \text { Pain change factors; } 2.6 \text { Modes of pain management; } 2.7 \text { Degree of pain. }\end{array}$ \\
\hline 3. Current and previous health status & 3.1 Personal history; 3.2 General health state; 3.3 Medications; 3.4 Allergies. \\
\hline 4. Physical assessment & $\begin{array}{l}\text { 4.1 General assessment; } 4.2 \text { Observations and exams; } 4.3 \text { Inspection; } 4.4 \text { Palpation and } \\
\text { percussion; } 4.5 \text { Peripheral pulses; } 4.6 \text { Spinal mobility; } 4.7 \text { Segment mobility; } 4.8 \text { Myotomes; } 4.9 \\
\text { Dermatomes; } 4.10 \text { Atrophy; } 4.11 \text { Osteotendinous reflex; } 4.12 \text { Signs of nerve root compression; } \\
4.13 \text { Segmental muscle strength; } 4.14 \text { Sensitivity; } 4.15 \text { Central nervous system Exam; } 4.16 \text { Other } \\
\text { exams (when pertinent). }\end{array}$ \\
\hline 5. Lifestyle & 5.1 Leisure, sports, home chores (activities and frequency); 5.2 Drug consumption. \\
\hline 6. Social and family history & 6.1 Social family situation; 6.2 Interpersonal relationships. \\
\hline 7. Financial situation & 7.1 Income; 7.2 ; Legal dispute. \\
\hline 8. Work environment & 8.1 Work context; 8.2 Work situation; 8.3 Work Regime; 8.4 Description of work tasks \\
\hline 9. Worker's perceptions and expectations & $\begin{array}{l}\text { 9.1 Perceptions concerning return to work (conditions, periods, barriers and facilitators, fears, } \\
\text { etc.); } 9.2 \text { Expectations; } 9.3 \text { Self-applied questionnaires. }\end{array}$ \\
\hline 10. Analysis of results and recommendations & $\begin{array}{l}\text { 10.1 Clinical abstract; } 10.2 \text { Presence of red flags; } 10.3 \text { weighted ISIT (Personal, Administrative, } \\
\text { Ergonomic); } 10.4 \text { Factors conducive to a potential return to work; } 10.5 \text { Recommendations. }\end{array}$ \\
\hline
\end{tabular}

Figure 1 - Sections and items addressed by the WoDDI

* Acronym in French 
Indicators for Work-Related Disability (ISIT) ${ }^{*}$ and Red Flags are identified in these ten areas. The ISIT are related to causes of prolonged disability and are classified into: Personal (P), Administrative (A) and Ergonomic (E). Red Flags indicate suspected severe pathologies and require immediate specific medical care. The administration of WoDDI requires the participation of two already trained clinicians over a period of two to five hours including a meeting for the interview, case discussion, and elaboration of recommendations. The time spent and corresponding costs, even though not usual, reflect a considerable gain for the interviewed workers, since this interview guide enables an early return to work, representing gains in cost-effectiveness ${ }^{(13)}$.

After data collection, the interviewers meet to consider the Indicators, establish the Work-Related Disability Diagnosis (DSIT) and define an intervention plan. It is extremely important to pay attention to ISIT and Red Flags throughout the interview because these support the proposition of intervention plan to return to work.

\section{Method}

This methodological study of cross-cultural adaptation was conducted according to international

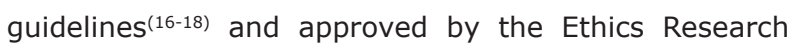
Committee at the University Hospital of São Paulo (Protocol CEP-HU/USP 818/08 - SISNEP-CAAE 0030.0.198.198.08). All the participant subjects voluntarily signed free and informed consent forms. The adaptation of WoDDI was authorized by the Center for Action in Work Disability and Rehabilitation (CAPRIT) at the Sherbrooke University, Canada, which retains the copyrights of the interview guide.

\section{Cross-cultural adaptation procedures}

Initial translation: two translations were made of the WoDDI French version to the Portuguese spoken in Brazil by two bilingual translators with distinctive backgrounds and knowledge, whose mother language was Portuguese. The first translator was familiar with concepts addressed in the interview guide to be translated and with the translation of health-related material. The second translator was not familiar with the concepts to be translated or with the clinical or medical fields.
Synthesis of the translations: a structured report of the synthesis of the two translations was developed based on the two independent versions, addressing the items and justification of the final consensus. A consolidated version was developed based on this synthesis.

Back translation: the produced version was then back-translated into French. This stage of the process took place in Montreal, Canada in cooperation with the CAPRIT team. Two independent bilingual translators whose mother language was French independently worked on the back translations indicating divergences and doubts. Once the back translations were finalized, a face-to-face meeting took place in Canada with researchers from both countries to consolidate the backtranslated version.

Expert committee: aiming to develop the penultimate version of the interview guide to be applied in the pretest, the committee was composed of six health professionals with considerable experience in treating Repetitive Strain Injury (RSI) and Work-Related Musculoskeletal Disorders (WRMD) and professional rehabilitation belonging to the Work-Related Musculoskeletal Disorders Study Group at the University Hospital of São Paulo. The version was analyzed in three meetings with an average duration of four hours each for conceptual, semantic, idiomatic, experiential and operational equivalence, as well as Content Validity Percentage(19-20), using the focal groups $^{(21)}$ technique to achieve consensus. The original questionnaire and all translations and back translations were provided, as well as the corresponding reports (explanation of the rationale used in each decision). Unlike other methods, the experts did not receive the material in advance for individual analysis. All had access to copies during the committee's meetings and instructions to analyze for equivalence; the copies were also projected during the meetings ${ }^{(15)}$. A minimum Content Validity percentage of $90 \%$ was adopted among the experts in the event total consensus was not achieved(19-20).

Penultimate version test: to verify the comprehensiveness of the interview guide, the version validated by the Experts Committee was applied to a sample of 30 workers linked to the University Hospital of São Paulo while in work leave for work-related reasons. A physician and a nurse, already trained for this purpose, applied the WoDDI. Each professional applied his/her

\footnotetext{
* Acronym in French
} 
part of the interview and at the end both reunited to consider the ISIT identified. The professionals took two hours on average to conduct the interview. Data collection was performed in the hospital's Primary Health Care Unit between August 2008 and May 2010.

Because the instrument combines many ways of approaching the interviewee, adjustments were considered in questions that were difficult to comprehend, observed in at least $15 \%$ of the participants ${ }^{(22)}$, and also in difficulties found by the interviewers to apply tests, maneuvers, and the physical assessment.

\section{Results}

Even though one of the translators presented a more accurate version in relation to the context of the initial translation, both translations were very close to the literal meaning contained in the WoDDI original version. Discussion during the meeting sought to synthesize the translations and included the topic of the 69 terms that diverged in the two translations. After consensus was reached concerning these terms, a consolidated version of the initial translation was attained.

The WoDDI's consolidated version was back translated into French to ensure that the translated version reflected the content of the items in the original version. The back translation process clarified some dubious terms that were discussed during the synthesis of the translations that were due to comprehension difficulties. In this stage, another 27 terms were changed - a fairly small number considering the various terms composing the WoDDI (the questionnaire is composed of approximately 3,000 words), which confirms the reliability of the translation process held in Brazil.

The analysis of conceptual, semantic, idiomatic, experiential and operational equivalence and content validation conducted by the Experts Committee were mainly directed to the practical applicability of the terms used in the interview. All items contained in the WoDDI, regardless of having been altered or not, were collectively evaluated by the Committee. A total of 27 terms presented Content Validity Percentage below $90 \%$ and for this reason they were changed, suppressed or new terms were added.

The penultimate version, established by the Experts Committee, was submitted to a pretest in a sample of the target population composed of 30 individuals, distributed as follows:

Table 1 - Distribution of socio-demographic characteristics of the participants in the pretest

\begin{tabular}{|c|c|c|}
\hline Characteristics & Frequency & $\%$ \\
\hline \multicolumn{3}{|l|}{ Gender } \\
\hline Female & 30 & 100.0 \\
\hline \multicolumn{3}{|l|}{ Age } \\
\hline $0-29$ years old & 1 & 3.3 \\
\hline 30-39 years old & 3 & 10.0 \\
\hline 40-49 years old & 17 & 56.7 \\
\hline 50-59 years old & 9 & 30.0 \\
\hline \multicolumn{3}{|l|}{ Function } \\
\hline Nursing auxiliary or technician & 20 & 66.7 \\
\hline Kitchen assistant & 4 & 13.3 \\
\hline Cleaning auxiliary & 3 & 10.0 \\
\hline Administrative assistant & 2 & 6.7 \\
\hline Laboratory technician & 1 & 3.3 \\
\hline \multicolumn{3}{|l|}{ Work sector } \\
\hline Nursery & 4 & 13.3 \\
\hline Food and Nutrition Service & 4 & 13.3 \\
\hline Medical Clinics & 3 & 10.0 \\
\hline Adult Emergency Department & 3 & 10.0 \\
\hline Child Emergency Department & 3 & 10.0 \\
\hline Administrative Sector & 2 & 6.7 \\
\hline Pharmacy & 2 & 6.7 \\
\hline Cleaning & 2 & 6.7 \\
\hline Pediatrics & 2 & 6.7 \\
\hline Rooming-in & 1 & 3.3 \\
\hline Surgery Clinic & 1 & 3.3 \\
\hline Primary Health Care Unit & 1 & 3.3 \\
\hline Adult Intensive Care Unit & 1 & 3.3 \\
\hline Child Intensive Care Unit & 1 & 3.3 \\
\hline
\end{tabular}

The period between the date of work leave, recorded in the hospital's Personnel Department, and the date the interview was held, was used to compute the period of work leave; previous work leave events were not taken into account. Hence, this period varied from one month to approximately six months $(17.4 \pm 23.6)$, while time working at the hospital varied from five and 27 years $(15.3 \pm 6.6)$. The cause of leave was most frequently related to WRMD, reported by 25 individuals (83.3\%), followed by depression in five individuals (16.7\%). In some cases, WRMD seemed to be associated with depression; in these cases, the main cause of leave was considered for the noted classification.

The pretest was put into operation according to the steps presented in Figure 2. 


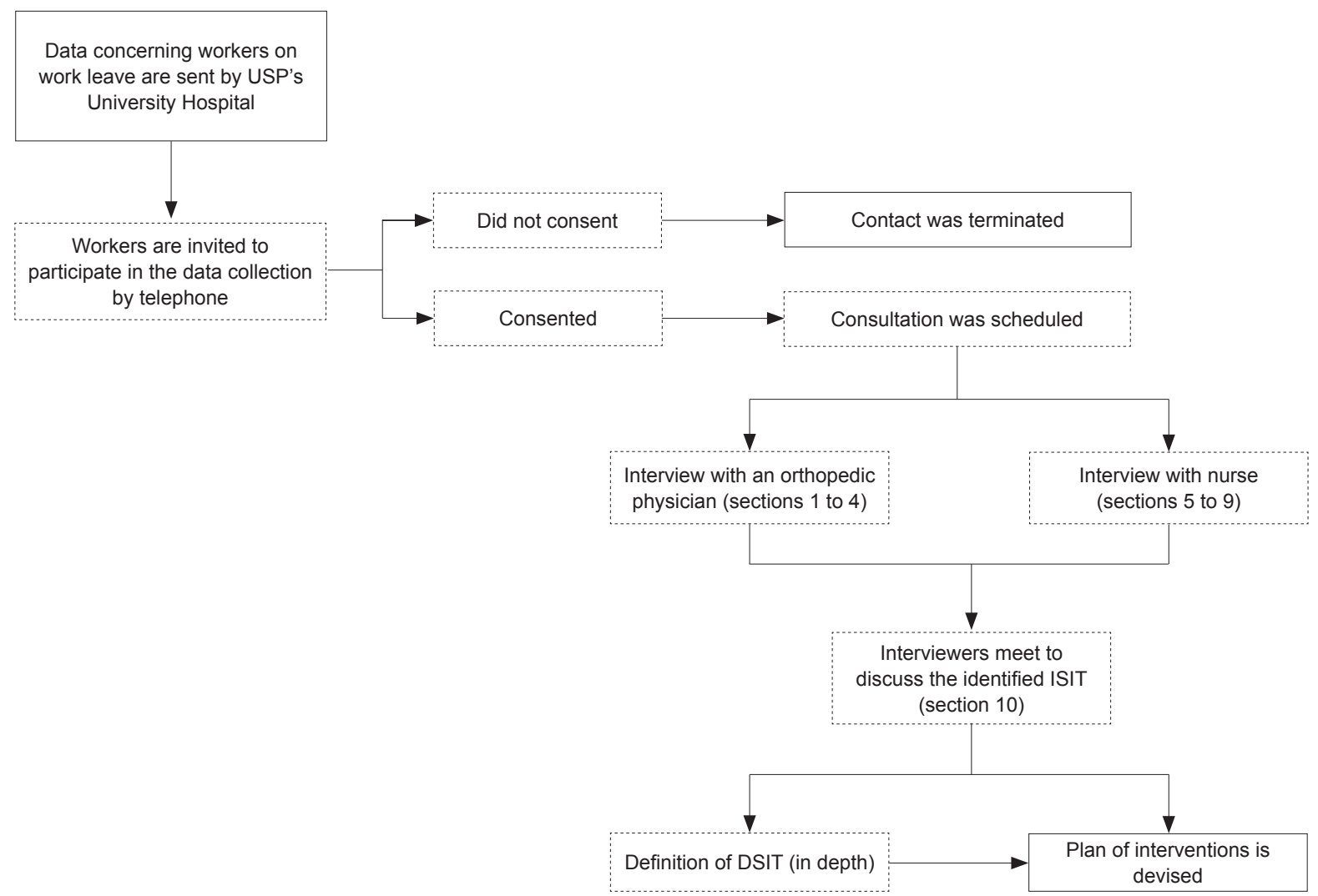

Figure 2 - WoDDI put into operation

Two perspectives concerning comprehensibility were evaluated in the pretest stage: the first is related to the interviewees' understanding of questions, for which a minimum percentage of $85 \%$ was established ${ }^{(21)}$; the second refers to the difficulties found by the interviewers in the application of the interview. Eighteen items were changed based on these criteria.

As a final result of the cross-cultural adaptation process, a manual with instructions on how to apply the WODDI was developed in order to provide tools for the professionals using it at work. For successful data collection, one needs to fully understand the sections and questions composing the questionnaire to evaluate the sufficiency of answers provided by the interviewees. Hence, following the order of the sections proposed in the WoDDI, the meanings of questions are presented as well as some synonyms that may help interviewers at the time they apply the interview, according to two examples presented in Figure 3.

\section{Section 2: Pain Syndrome}

2.1.1 Site of pain

Interpretation: to identify the site of pain. For that, there is a figure to describe the site and pain pathway: cervical, dorsal, dorsolumbar, lumbar, lumbosacral, shoulder, arm, elbow, forearm, wrist, hand, hip, thigh, knee, leg, ankle, foot or other. Check the correct side of pain (left or right)

Ways to question: where is your pain located? Where does it hurt? What part of your body hurts?

\section{Section 4: Physical Assessment}

4.12 Signs of root compression

a) Tripod maneuver: place the respondent in supine position; bend one knee forming a $90^{\circ}$ angle. Make dorsiflexion in one foot, also forming a $90^{\circ}$ angle. Check whether it is positive or negative in both limbs. If the interviewee manifests sciatica, the Tripod Maneuver will be positive, otherwise negative. The following figure shows this maneuver:

a)

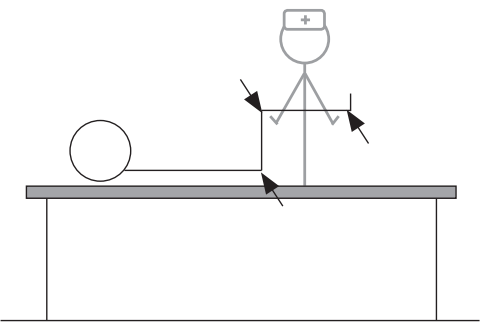

Figura 3 - Examples extracted from the WoDDI manual 
The definition of concepts and meanings of ISIT composing the WoDDI were extracted from a document containing instructions concerning the interview guide developed by the Canadian researchers. These are available in detailed form to facilitate the understanding of and deliberation over each Indicator. This material was freely translated and adapted to Portuguese based on WoDDI training, discussions with the research team in Canada and with the Experts Committee, and on experience acquired while applying the pretest, as well.

Similarly, the protocol containing the steps to be taken when Red Flags are identified as recommended by CAPRIT was also translated and adapted. This protocol indicates what actions should be taken if the interviewee presents indications of severity.

\section{Discussion}

The WoDDI cross-sectional adaptation process complied with recommendations internationally adopted for this type of study, ensuring conceptual, semantic, idiomatic, experiential, and operational equivalence of the interview guide ${ }^{(16-18)}$, as well as Content Validity(19-20).

It is worth noting it was an important achievement to perform the back translation in the instrument's country of origin due to the possibility of discussing potential doubts and uncertainties accruing from the translation process with the instrument's developers. Since the back translation process evaluates the consistency of the initial translation, it aids in the correction of errors that may be related to the literal translation itself, or to the interpretation embedded in the translated term. It is possible that performing the back translation in the country of origin would not confer such an advantage if not for the discussion that took place among the researchers from both countries.

Even though this is not a recurrent practice in processes of cross-cultural adaptation and there is no indication of it in the literature, we believe, based on this experience, that opting for this procedure is very relevant in the case of instruments with open questions. When this phase cannot be performed in the country of origin, we recommend a meeting with the instrument's developers immediately after back translation to clarify potential doubts and/or uncertainties in order to facilitate and enrich analysis with the Experts Committee. The discussion in the focus groups with the committee were enriching in this phase of the process. Even though this technique is not largely applied in cross-cultural adaptation studies, the achievement of consensus through a collective process of reflection on a given item's content showed it might be a new method to evaluate qualitative research instruments.
Another difference from the norm that corroborated this stage of cross-cultural adaptation was that the experts attended a training program in advance covering the use of the interview guide in Brazil. As a previous contact with WoDDI had already been established, including a hypothetical application of it during training, the experts knew the proposed items and areas, which optimized discussions and reaching consensus. As a final result, irrelevant, inadequate or ambiguous items were suppressed and replacements, more appropriate to the target population, were created while keeping the general concept of the changed items and ensuring the understanding of the translated final version ${ }^{(23)}$.

Unlike some self-applied questionnaires in which the interviewee reads and answers questions in an independent way, the questions contained in the interviews are asked by an interlocutor who can use auxiliary synonyms for words not understood by respondents, as long as the original meaning of the question is not compromised.

To facilitate the application of the instrument by the interviewer, an instruction manual was developed. It contains auxiliary questions for items that present any potential difficulty of understanding that might not be detected in the pretest. The objective was to maintain the original question and support the interviewer in cases where the respondent does not understand the question or answers it incorrectly.

The questions, tests, maneuvers and exams, as well as ISIT and Red Flags, are conceptualized and detailed in this manual to ensure full understanding for the interviewer at the time of the interview. Even though these are extremely clarifying strategies they do not replace training professionals in the use of the WoDDI prior to performing the interviews. Training is a necessary and indispensable premise for realizing all the potential contained in this interview guide.

\section{Conclusion}

This study's results show that the Work Disability Diagnosis Interview guide is successfully adapted for the Brazilian situation and can be used by professionals and services interested in work-related disability.

Even though it was analyzed in the context of hospitals, this interview guide can (and should) be applied in the various productive sectors of Brazil because it enables the investigation of intervenient dimensions in the process of disability and return to work.

Even though data obtained during the application of the WoDDI were not analyzed at this point, they are a priceless possession because they encompass the perceptions, thoughts and feelings of workers concerning 
themselves, their health and work relations, in addition to a complete physical assessment that resulted in a detailed situational diagnosis of the case. Moreover, the establishment of bonds with workers during the interviews greatly advanced the final interpretation of data obtained from the respondents.

\section{References}

1. Magnago TSBS, Lisboa MTL, Griep RH, Kirchhof ALC, Camponogara S, Nonnenmacher $\mathrm{CQ}$, et al. Condições de trabalho, características sociodemográficas e distúrbios musculoesqueléticos em trabalhadores de enfermagem. Acta Paul Enferm. 2010;23(2):187-93.

2. Sancinetti TR, Gaidzinski RR, Felli VEA, Fugulin FMT, Baptista PCP, Ciampone MHT, et al. Absenteísmo: doença na equipe de enfermagem: relação com a taxa de ocupação. Rev Esc Enferm USP. 2009;43(2):1277-83.

3. Schimidt DRC, Dantas RAS, Marziale MHP, Laus AM. Estresse ocupacional entre profissionais de enfermagem do bloco cirúrgico. Texto Contexto Enferm. 2009:18(2):330-7.

4. Gurgueira GP, Alexandre NMC, Corrêa-Filho HR. Self-reported musculoskeletal symptoms among nursing personnel. Rev. Latino-Am. Enfermagem. 2003;11(5):608-13.

5. Barboza DB, Soler ZASG. Nursing absenteeism: occurrences at a university hospital. Rev. Latino-Am. Enfermagem. 2003;11(2):177-83.

6. Silva DMPP, Marziale MHP. Absenteeism of nursing workers from a university hospital. Rev. Latino-Am. Enfermagem. 2000;8(5):44-51.

7. Ministério da Previdência e Assistência Social (BR). Anuário Estatístico de Acidente do Trabalho 2008. Brasília, 2008 [acesso 16 ago. 2009]. Disponível em: http://www.previdenciasocial.gov.br/arquivos/ office/3_091028-191015-957.pdf

8. Lloyd C, Waghnorn G, McHugh C. Musculoskeletal disorders and comorbid depression: implications for practice. Aust Occ Ther J. 2008;55:23-9.

9. Vigatto $R$, Alexandre NM, Corrêa-Filho HR. Development of a Brazilian Portuguese version of the Oswestry Disability Index: cross-cultural adaptation, reliability, and validity. Spine. 2007;32(4):481-6.

10. Orfale AG, Araújo PMP, Ferraz MB, Natour J. Translation into Brazilian Portuguese, cultural adaptation and evaluation of the reliability of the Disabilities of the Arm, Shoulder and Hand Questionnaire. Braz J Med Biol Res. 2005;38(2):293-302.

11. Alexandre NMC, Barros ENC. Cross-cultural adaptation of the Nordic musculoskeletal questionnaire. Int Nurs Rev. 2003;50(2):101-7.
12. Nusbaum L, Natour J, Ferraz MB, Golderberg J. Translation, adaptation and validation of the RolandMorris Questionnaire - Brazil Roland-Morris. Braz J Med Biol Res. 2001;34(2):203-10.

13. Durand $M J$, Loisel $P$, Hong QN, Charpentier $N$. Helping clinicians in work disability prevention: the Work Disability Diagnosis Interview. J Occu Rehabil. 2002:12(3):191-204.

14. Loisel $P$, Charpentier N, Felli VAE, Durand MJ, CostaBlack K, Mininel VA, et al. Cross-cultural adaptation of the Work Disability Diagnostic Interview (WoDDI) for a Brazilian context. Report present to Réseau provincial de recherche en adaptation-réadaptation (REPAR); 2007. $10 \mathrm{p}$.

15. Loisel P, Durand P, Abenhaim L, Gosselin L, Simard R, Turcotte J, el al. Management of occupational back pain: the Sherbrooke model Results of a pilot feasibility study. Occup Environ Med. 1994;51:597-602.

16. Beaton DE, Bombardier C, Guillemin F, Ferraz MB. Guidelines for the process of cross-cultural adaptation of self-report measures. Spine. $2000 ; 25(24)$ : 3186-91.

17. Guillemin F. Cross-cultural adaptation and validation of health status measures. Scand J Rheumatol. $1995 ; 24(2): 61-3$.

18. Guillemin F, Bombardier C, Beaton D. Cross-cultural adaptation of health-related quality of life measures: literature review and proposed guidelines. J Clin Epidemiol. 1993;46:14-32.

19. Wynd CA, Schmidt B, Schaefer MA. Two quantitative approaches for estimating content validity. West J Nurs Res.2003;25(5):508-18.

20. Tilden VP, Nelson CA, May BA. Use of qualitative methods to enhance content validity. Nurs Res. 1990;39(3):172-5.

21. Chiesa AM, Ciampone MHT. Princípios gerais para abordagem de variáveis qualitativas e o emprego da metodologia de grupo focais. Brasília: Classificação Internacional das Práticas em Saúde Coletiva; 1999. p. 306-24.

22. Ciconelli RM, Ferraz MB, Santos W, Meinão I, Quaresma MR. Tradução para a língua portuguesa e validação do questionário genérico de avaliação de qualidade de vida SF-36 (Brasil SF-36). Rev Bras Reumatol. 1999;39(3):143-50.

23. Alexandre NMC, Guirardello EB. Adaptación cultural de instrumentos utilizados en salud ocupacional. Rev Panam Salud Publica. 2002;11(2):109-11. 